DOI: 10.46340/eujem.2020.6.6.6

\author{
Svitlana Honchar \\ ORCID ID: https://orcid.org/0000-0002-7420-962X \\ Lviv Polytechnic National University, Ukraine \\ Olena Ugolkova, PhD in Economics \\ ORCID ID: https://orcid.org/0000-0003-0290-9130 \\ Lviv Polytechnic National University, Ukraine \\ Nataliia Reverenda, PhD in Economics \\ ORCID ID: https://orcid.org/0000-0002-7712-8999 \\ Lviv Polytechnic National University, Ukraine
}

\title{
ANAL YSIS OF THE FEATURES OF CREDIT \\ AND INVESTMENT POLICY ON THE EXAMPLE OF UNITED STATES, UNITED KINGDOM \\ AND JAPAN
}

\author{
Світлана Гончар \\ Олена Уголькова, к.е.н. \\ Наталія Реверенда, к.е.н. \\ Національний університет "Львівська політехніка», Україна
}

\section{АНАЛІЗ ОСОБЛИВОСТЕЙ КРЕДИТНО-ІНВЕСТИЩЙНОЇ ПОЛІТИКИ НА ПРИКЛАДІ США, ВЕЛИКОБРИТАНІЇ ТА ЯПОНІї}

\begin{abstract}
The article analyzes the approaches of scientists to define the concept of credit and investment policy. Also the articleoffers the author's interpretation of this term. The experience of developed countries (USA, Great Britain and Japan) in the field of credit and investment policy is analyzed. The key functions and main features of the activity of regulatory authorities in this area are researched. In addition, the fundamental provisions of the legislative regulation of credit and investment activities in theses countries are described. It is concluded that there is at least one regulatory authority in every analyzed countries, the main purpose of which is to protect the rights of consumers and investors, to ensure open and fair realization of credit and investment activities, and to promote security and efficiency of payments and reliability of the entire financial and investment system institutions.
\end{abstract}

Key words: credit and investment policy, credit activity, investment climate, legislative regulation, resources, investors.

Постановка проблеми. У сучасних економічних умовах кредитна та інвестиційна діяльність $\epsilon$ важливою складовою фінансової сфери держави та активно впливає на усі ії макроекономічні показники. Окремі аспекти такої діяльності регулюються відповідними державними органами та спеціалізованими законами. Однак динамічні зміни у суспільстві, активна діджиталізація, поява нових фінансових інструментів та інвестиційних моделей вимагає комплексного рішення, яким, на нашу думку, $є$ постійне вдосконалення кредитно-інвестиційної політики на рівні держави. Поняття кредитно-інвестиційної політики $є$ багатогранним та характеризується значною кількістю особливостей та, як наслідок, потребує глибокого наукового дослідження.

Аналіз останніх досліджень і публікацій. Проведене дослідження показало, що більшість науковців у даній сфері у своїх працях розглядають кредитно-інвестиційну політику лише 3 двох окремих сторін: або кредитну політику, або інвестиційну політику. 
До прикладу, вітчизняний науковець Карбівничий I.В. ${ }^{1}$ акцентує власну увагу на кредитній політиці та пропонує розглядати іiі як сукупність дій, «спрямованих на управлінні кредитним потенціалом та внутрішніми кредитними процесами», а також «на управління діяльністю його клієнтів».

Дослідники Русіна Ю.О. та Ковтун М.В. ${ }^{2}$ переконані, що кредитну політику варто розглядати як «структурно-функціональну цілісність взаємопов'язаних між собою елементів (цілей, завдань, принципів, технологій, організацій), взаємодія яких дає змогу визначити найбільш ефективні стратегії діяльності на ринку кредитних послуг».

Значна частина праць, що стосуються кредитної політики, розглядає це поняття лише на мікрорівні, тобто на рівні окремого підприємства чи фінансово-кредитної установи, і абсолютно не досліджується кредитна політика на рівна держави.

Інша когорта науковців займаються вивченням поняття інвестиційної політики та її складових. Так, Цанько O. ${ }^{3}$ розглядає державну інвестиційну політику як «діяльність держави щодо регулювання процесу інвестування з метою виконання основних соціально-економічних цілей розвитку країни, комплекс економічних, організаційно-правових та інших заходів держави, спрямованих на створення сприятливого інвестиційного клімату, структурну перебудову, підвищення ефективності національного господарства».

Шевердіна O. ${ }^{4}$ переконана, що державна інвестиційна політика є «складником економічної політики держави, що включає комплекс правових, адміністративних та економічних заходів, що провадиться з метою поширення та активізації інвестиційних процесів, а також регулювання капіталовкладень для контролю над структурною перебудовою виробництва, його технічного та технологічного оновлення і модернізації».

Існує також інша частина дослідників, що аналізують стан та характеристики кредитноїінвестиційної політики лише в контексті монетарної політики. Закордонний дослідник Н. Туркеші ${ }^{5}$ досліджує як процентні ставки та облікова ставка центрального банку впливає на макроекономічні показники держави. Вітчизняні науковці М.Е. Люзняк та О.М. Бартош ${ }^{6}$ аналізували вплив інструментів монетарної політики центрального банку на кредитний ринок держави.

Отже, потребує детального вивчення комплексне поняття кредитно-інвестиційної політики держави, його характеристики, особливості та найкращі практики у світі.

Цілі статті. Метою даної статті є дослідження поняття «кредитно-інвестиційної політики держави», а також аналіз особливостей ii реалізування в розвинених країнах світі 3 метою адаптування найкращих практик до українських реалій.

Виклад основного матеріалу дослідження. Кредитно-інвестиційна політика $є$ елементом економічної політики держави, який складається з організаційно-правових та економічних заходів, що розвивають кредитно-інвестиційну діяльність, регулюють використання кредитних та інвестиційних ресурсів з метою забезпечення збалансованого розвитку національної економіки.

Кожна держава характеризується певними особливостями у провадженні власної кредитноінвестиційної політики. Проте є певні ключові приклади розвинених держав, і саме кредитноінвестиційна політика таких країни була об'єктом дослідження.

Варто розпочати з аналізування досвіду США, так як ця країна завжди очолює рейтинги за обсягами інвестицій, за легкістю ведення бізнесу, за операціями фінансування тощо.

\footnotetext{
${ }^{1}$ Карбівничий, І. В. (2011). Механізм формування та реалізації кредитної політики банку: автореферат дисертації на здобуття наукового ступеня кандидата економічних наук. Суми: Українська академія банківської справи Національного Банку України. Electronic Sumy State University Institutional Repository <https://essuir.sumdu.edu.ua/bitstream-download/123456789/51574/1/Karbivnychuj_credit_policy_ in_banks.pdf;jsessionid=1D23801CD55539E8B732560AC0F960B7>(2020, жовтень, 15).

2 Русіна, Ю. О., Ковтун, М. В. (2014). Механізм формування та реалізації кредитної політики банку. Економіка. Управління. Інновації, 1 (11) <http://nbuv.gov.ua/UJRN/eui_2014_1_52> (2020, жовтень, 15).

${ }^{3}$ Цанько О. (2016). Теоретичні основи формування інвестиційної політики: регіональний аспект. Ефективність державного управління, 1/2(46/47), 92-99.

${ }^{4}$ Шевердіна, О. (2012). Інвестиційна політика України як об’єкт державної економічної політики. Державна політика, 4, 111-117.

${ }^{5}$ Turkeshi, N. (2016). The impact of monetary instruments in the development of monetary policy in the republic of Macedonia. Academic Journal of Interdisciplinary Studies, 5 (3 S1). DOI: 10.5901/ajis.2016.v5n3s1p539.

6 Люзняк, М. Е., Бартош, О. М. (2011). Інструменти грошово-кредитної політики НБУ та їх вплив на депозитний і кредитний ринки. Ефективна економіка, 12. 〈http://nbuv.gov.ua/UJRN/efek_2011_12_21> (2020, листопад, 25).
} 
Американська модель кредитно-інвестиційної політики характеризується такими основними суб'єктами ${ }^{1}$ :

- центральний банк CША (U.S. Central Bank)

- рада керівників Федерального резерву (Federal Reserve Board of Governors)

- 12 федеральних резервних банків (Federal Reserve Banks)

- Федеральний комітет відкритого ринку (Federal Open Market Committee, FOMC)

- комісія з цінних паперів і бірж США (U.S. Securities and Exchange Commission, SEC).

Центральний банк, рада керуючих, федеральні банки та комітет відкритого ринку є складовими федеральної резервної системи. Загалом їх основними спільними функціями $є$ такі:

- сприяння максимальній зайнятості, стабільним цінам та помірним довгостроковим процентним ставкам в економіці США;

- сприяння стабільності фінансової системи та мінімізування системних ризиків шляхом активного моніторингу;

- сприяння безпеці та надійності окремих фінансових установ та контролювання їх впливу на фінансову та інвестиційну системи.

Центральний банк впливає на 12 федеральних банків. Ці установи працюють самостійно, але під наглядом і центрального банку, і ради керівників та комісії відкритого ринку.

Спочатку передбачалося, кожен 312 резервних банків мав працювати незалежно від інших резервних банків та навіть самостійно встановлювати процентні ставки. Концепція формування національної економічної політики була недостатньо розробленою, і вплив операцій на відкритому ринку - купівлі та продажу державних цінних паперів США - на формування політики був менш значним.

У зв'язку з збільшенням інтегрованості держави та завдяки розвитку технологій, зв'язку, транспорту та фінансових послуг, ефективне проведення монетарної політики почало вимагати посиленої співпраці та координації у всій системі, як наслідок було Раду керуючих, тобто агентство федерального уряду, яке звітує перед Конгресом і підпорядковується йому безпосередньо, надає загальні вказівки для фінансово-кредитної системи та контролює 12 резервних банків².

Рада керуючих, Федеральний резервний банк (резервні банки) та Федеральний комітет відкритого ринку (FOMC) приймають рішення, що сприяють зміцненню економіки США та стабільності фінансової системи США. Конгрес контролює систему Федерального резервного резерву та її суб'єкти. Рада губернаторів - незалежне агентство федерального уряду ${ }^{3}$.

Надзвичайно важливу роль відіграє Комісія з цінних паперів та бірж (SEC) - американський наглядовий орган, відповідальний за регулювання ринків цінних паперів та захист інвесторів. SEC була створена прийняттям Закону США про цінні папери 1933 року та Закону про цінні папери та біржі 1934 року, головним чином у відповідь на крах фондового ринку 1929 року, що призвів до Великої депресії.

Основна функція SEC - це нагляд за організаціями та приватними особами на ринках цінних паперів, включаючи біржі цінних паперів, брокерські фірми, дилерів, інвестиційних радників та інвестиційні фонди. Завдяки встановленим законам та правилам щодо цінних паперів SEC сприяє розкриттю та обміну ринковою інформацією, чесній торгівлі та захисту від шахрайства. Він надає інвесторам доступ до заяв про реєстрацію, періодичних фінансових звітів та інших форм цінних паперів через свою електронну базу даних збору, аналізу та пошуку ${ }^{4}$.

SEC складається 3 п’яти відділів та 24 офісів. Їх цілі- тлумачити та вживати заходів щодо виконання законів про цінні папери, видавати нові правила, забезпечувати нагляд за діяльністю установ цінних паперів та координувати регулювання між різними рівнями управління.

П’ять основних підрозділів та їх відповідні ролі:

- Відділ корпоративних фінансів: гарантує, що інвестори отримують інформацію, що стосується фінансових перспектив компанії або ціни акцій для прийняття обгрунтованих інвестиційних рішень.

\footnotetext{
${ }^{1}$ Board of Governors of the Federal Reserve System (2020). Recent Developments

$<$ https://www.federalreserve.gov/aboutthefed/structure-federal-reserve-system.htm> (2020, листопад, 23).

2 Там само.

${ }^{3}$ Federal Open Market Committee (2020). Federal Open Market Committee

<https://www.newyorkfed.org/aboutthefed/fedpoint/fed48.html> (2020, листопад, 26).

${ }^{4}$ SEC (2020). Homepage <https://www.sec.gov/> (2020, листопад, 23).
} 
- Відділ примусового виконання: відповідальний за забезпечення виконання норм SEC шляхом розслідування справ та переслідування цивільних позовів та адміністративних проваджень.

- Відділ управління інвестиціями: регулює діяльність інвестиційних компаній, змінних страхових продуктів та федеральних зареєстрованих інвестиційних радників.

- Відділ економічного аналізу та аналізу ризиків: інтегрує економіку та аналіз даних в основну місію SEC.

- Відділ торгівлі та ринків: встановлює та підтримує стандарти справедливих, упорядкованих та ефективних ринків.

Серед усіх офісів SEC, Бюро викривачів виділяється як один із найпотужніших засобів забезпечення правопорядку. Програма SEC, що подає повідомлення про винагороду, винагороджує осіб, що відповідають вимогам, за обмін оригінальною інформацією, що призводить до успішних правоохоронних дій із грошовими санкціями на суму понад 1 млн доларів. Фізичні особи можуть отримати від $10 \%$ до $30 \%$ від загальної виручки санкцій.

Сьогодні SEC щороку проводить численні цивільно-виконавчі дії проти фірм та приватних осіб, які порушують законодавство про цінні папери. Типові правопорушення, які переслідуються SEC, включають шахрайство з бухгалтерським обліком, розповсюдження оманливої або неправдивої інформації та торгівлю особами, що інсайдерські.

Основними законами, що регулюють кредитно-інвестиційну діяльність в США, є такі: Закон про дерегуляцію та монетарний контроль депозитарних установ 1980 року, Jumpstart Our Business Startups (JOBS) Act of 2012, Dodd-Frank Wall Street Reform and Consumer Protection Act of 2010, Sarbanes-Oxley Act of 2002. 3 точки зору інвестиційного права, надзвичайно важливим є закон, прийнятий президентом США Б.Обамою Jumpstart Our Business Startups (JOBS) Act у 2012 р. Цей закон послаблює правила щодо звітування, контролю та рекламування для компаній, які намагаються залучити кошти інвесторів.

Цікаво, що цей закон обмежую суму, яку фізичні особи можуть вкладати інвестиції. Обмеження полягають у тому, що фізичні особи, чий валовий дохід складає до 100000 дол. США в рік, можуть інвестувати лише максимально до 2000 дол. США, а інвестори з доходом більше 100000 дол. США мають обмеження у розмірі $10 \%$ від річного доходу (рис.1).

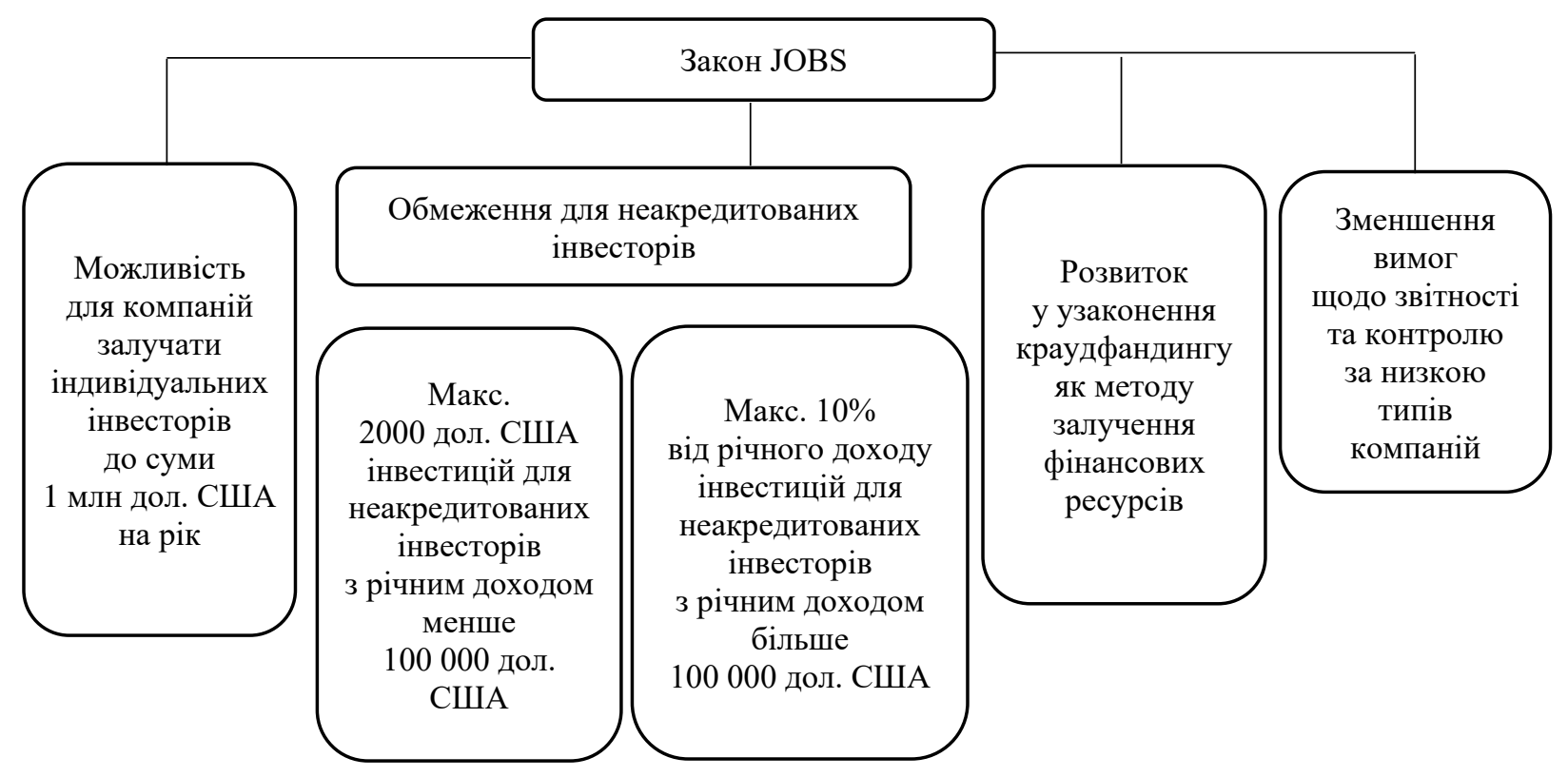

Рис. 1. Ключові положення закону JOBS ${ }^{1}$

\footnotetext{
${ }^{1}$ The White House (2012). President Obama To Sign Jumpstart Our Business Startups (JOBS) Act $<$ https://obamawhitehouse.archives.gov/the-press-office/2012/04/05/president-obama-sign-jumpstart-our-businessstartups-jobs-act> (2020, листопад, 13).
} 
Закон США обмежує суму потенційних інвестицій з метою захисту населення від можливого банкрутства, так як вкладання коштів в стартапи за допомогою краудфандингу чи інших методів не гарантує повернення коштів та прибутку.

Варто також зазначити, що за оцінками експертів такий закон дозволяє залучити до інвестиційної сфери значну кількість коштів, які раніше не використовувалися. Середня сума інвестицій на людину в США складає 12000 дол. США. Якщо додатково залучаться завдяки закону хоча б 25000 людей, то економіка одержає 300 млн дол США нових інвестицій ${ }^{1}$.

Щодо Великобританії, то у цій країні є два ключові регулятори. Орган пруденційного регулювання (“PRA”) відповідає за фінансову безпеку та надійність банків. Орган фінансового регулювання і нагляду Великобританії (FCA) відповідає за те, як банки ставляться до своїх клієнтів та поводяться на фінансових ринках.

Мета FCA - забезпечити належне функціонування відповідних ринків і вони ставлять перед собою такі оперативні цілі: захистити споживачів; захистити фінансові ринки; сприяти конкуренції в інтересах споживачів. FCA є незалежним державним органом, який повністю фінансується фірмами, які знаходяться під регулюванням, шляхом стягнення з них зборів. Цей орган $є$ підзвітним Казначейству, яке відповідає за фінансову систему Великобританії, та парламенту².

Орган пруденційного регулювання (PRA) є частиною Банку Англії і відповідає за пруденційне регулювання та нагляд за банками, кредитними спілками, страховиками та основними інвестиційними фірмами. Він встановлює стандарти та здійснює нагляд за фінансовими установами на рівні окремої фірми. Загалом PRA регулює приблизно 1700 фінансових фірм. PRA має дві статутні цілі: сприяти безпеці та надійності цих фірм; сприяти забезпеченню належного рівня захисту для страхувальників (для страховиків). Це робить важливий внесок у основну мету Банку - захист та підвищення стабільності фінансової системи Великобританії3.

За допомогою регулювання PRA встановлює стандарти, які фірми повинні виконувати, та контролює їх відповідність. PRA використовуватиме власне судження щодо того, чи фінансові фірми безпечні та надійні, чи забезпечують страховики належний захист страхувальникам і чи продовжують компанії виконувати порогові умови.

Фінансова та інвестиційна діяльність в Великобританії регулюється Законом 2000 про фінансові послуги та ринки (Financial Services and Markets Act 2000 (FSMA). До цього Закону термін "дотримання вимог" був відносно незнайомим i розглядався як низький пріоритет у господарській діяльності. FSMA був представлений як повний, точний та доступний документ, що детально описує ролі та відповідальність фінансових послуг та ринкових галузей. Хоча багато його частин було скасовано або змінено, це настільки ж важливе законодавство, яке запровадило Управління фінансових послуг (FSA) як регулятор для страхування, інвестиційного бізнесу та банківської діяльності. FSMA також відомий тим, що окреслив регулятивні цілі Органу фінансової поведінки (FCA). Ці обов'язки включають довіру до ринку, фінансову стабільність, обізнаність громадськості, захист споживачів та зменшення фінансової злочинності ${ }^{4}$.

Через підвищення законодавства багато частин FSMA були скасовані. Однак нормативні акти забезпечують основу для більшої частини пізнішого законодавства, включаючи Закон про фінансові послуги 2012 року та Закон про Банк Англії та Закон про фінансові послуги 2016. Зміни до фінансових послуг, запроваджені FSMA, сприяли покращенню обслуговування споживачів, кращому співвідношенню для грошові товари та послуги, а також чіткіша, корисніша інформація.

Споживачі можуть відчувати себе в безпеці, знаючи, що існують довірені дозволи та регуляторні системи, які працюють над тим, щоб забезпечити відповідність підприємств законодавству, такому як FSMA.

\footnotetext{
${ }^{1}$ Farrell, J., Hedges, K. (2012). The JOBS Act: What Startups and Small Businesses Need to Know [Infographic]. Forbes $<$ https://www.forbes.com/sites/work-in-progress/2012/09/21/the-jobs-act-what-startups-and-small-businessesneed-to-know-infographic/?sh=73f4baf11067> (2020, листопад, 18).

${ }^{2}$ FCA (2020). Нomepage $<\mathrm{https}: / /$ www.fca.org.uk/> (2020, листопад, 10).

${ }^{3}$ Bank of England (2020). Prudential regulation <https://www.bankofengland.co.uk/prudential-regulation> (2020, листопад, 05).

${ }^{4}$ Global Legal Insights (2020). Regulatory architecture: overview of banking regulators and key regulations <www.globallegalinsights.com/practice-areas/banking-and-finance-laws-and-regulations/united-kingdom\#chaptercontent2> (2020, листопад, 03).
} 
Відповідно до інвестиційної схеми підприємства фізичні особи можуть отримати податковий кредит до $30 \%$ від вартості, вкладеної в кваліфіковані акції, на інвестиції до: 1 мільйон фунтів стерлінгів на рік; 2 мільйони фунтів стерлінгів на рік, якщо щонайменше 1 мільйон фунтів стерлінгів інвестується у наукомісткі компанії; 200000 фунтів стерлінгів на рік, якщо інвестувати їх у компанії довірчого венчурного капіталу.

Більш велика допомога у розмірі 50\% доступна для інвестицій до 100000 фунтів стерлінгів у малі починаючі компанії за інвестиційною схемою насіннєвих підприємств (SEIS).

На додаток до пільги з податку на прибуток, дивіденди, отримані від звичайних акцій, звільняються від податку на прибуток.

В даний час не існує вимог до кваліфікації для тих, хто управляє інвестиціями для інституційних клієнтів.

Однак багато фірм вирішують слідувати вказівкам у Довіднику FCA і вимагати, щоб їхні працівники отримували кваліфікацію як спосіб демонстрації компетентності.

Особи, які управляють інвестиціями для роздрібних клієнтів, мають вимогу отримати відповідну кваліфікацію.

Сертифікат управління інвестиціями (Investment Management Certificate) - це відповідна кваліфікація, запропонована CFA UK. Це охоплює різні види діяльності, включаючи "управління інвестиціями".

За рік проводяться понад 5000 засідань іспитів IMC. Приблизно 25\% кандидатів здобувають кваліфікацію з регуляторних причин.

Mifid II набув чинності 3 січня 2018 року та включає нові вимоги до підготовки та компетентності для тих, хто «надає інформацію» та / або «надає інвестиційні поради». Як наслідок, що багато інвестиційних менеджерів було класифіковано як „тих, хто надає інформацію”.

Інвестиційне об'єднання (Investment association) також відіграє важливу роль. Воно є торговим органом та галузевим голосом британських інвестиційних менеджерів.

Унікальність Великобританії полягає у тому, що надзвичайно важливим фактором виклику отримання інвестицій у Великобританії є право компанії на отримання SEIS / EIS.

Схема підприємницьких інвестицій (EIS) та Схема інвестиційних проектів насінницьких підприємств (SEIS) - це дві державні програми, створені для стимулювання інвестицій в інноваційні стартапи шляхом значних податкових пільг.

SEIS охоплює компанії на дуже ранніх стадіях, як це випливає з абревіатури, в основному на стадіï Seed. Ця схема дозволяє будь-якій окремій особі інвестувати 100000 фунтів стерлінгів кожного податкового року та отримувати податкову пільгу на $50 \%$.

EIS дозволяє фізичній особі інвестувати до 1000000 фунтів стерлінгів на податковий рік та отримати податкову пільгу на $30 \%$. Для компаній максимальне фінансування EIS, яке вони можуть отримати, становить 12000000 фунтів стерлінгів.

У той же час, як в EIS, так і в SEIS, є додаткова перевага, що не потрібно платити податок на спадщину з акцій, що належать як мінімум на два роки. I якщо акції продаються в будь-який момент і реєструється збиток, ці збитки можуть бути компенсовані податковим навантаженням на прибуток від капіталу інвестора.

Японія є країною із сильним залученням портфельних інвестицій та активним зовнішнім прямим іноземним інвестором із рівнем прямих іноземних інвестицій більше 10 млрд. доларів США на 2017 рік. Основними джерелами прямих іноземних інвестицій в Японію є США, Франція, Нідерланди, Сінгапур, Кайманові острови та Швейцарія, що разом становило близько $80 \%$ від загальної суми прямих іноземних інвестицій.

Загалом, ключовими галузями для інвесторів в Японії є страхування, електричні машини та транспортне обладнання. Реформи у фінансовому секторі та секторі комунікацій спонукали ріст в прямі іноземні інвестиції в ці галузі також протягом останніх років.

У Японії використовують систему цивільного права, спочатку засновану на європейських правових моделях, особливо в Німеччині та Франції. Японія створила свою сучасну правову систему, коли імператорське правління було відновлено завдяки Реставрації Мейдзі в 1868 році. Після поразки Японії у Другій світовій війні була розроблена нова конституція із значним впливом США. Сучасна японська правова система стала дещо схожим на гібрид континентального та американського законодавчих впливів. 
Конституція Японії приймає представницьку парламентську демократію та передбачає поділ влади на три гілки :

- Сейм (The Diet) (законодавча).

- Кабінет (Cabinet ) (виконавча).

- Верховний суд (судова влада).

Прем’єр-міністр як глава кабінету міністрів призначається більшістю резолюцій сейму. Палата представників, нижча $з$ двох палат, може вирішувати клопотання про недовіру Кабінету міністрів, в цьому випадку всі члени Кабміну повинні подати у відставку, за умови повноважень Кабміну розпустити Палату представників.

Для підтримання стабільності фінансової системи та захисту споживачів були встановлені мінімальні вимоги до капіталу, мінімальні вимоги до чистих активів або мінімальні вимоги щодо забезпечення щодо компаній, які займаються наданням фінансових, платіжних, страхових та інших супутніх послуг, у тому числі згідно наступне ${ }^{2}$ :

- Закон про банківську діяльність.

- Закон про фінансові інструменти та обмін.

- Бізнес-закон про грошове кредитування.

- Закон про страховий бізнес.

- Закон про платіжні послуги.

Наприклад, нещодавно встановлено мінімальну вимогу до капіталу в розмірі 10 мільйонів JPY для внутрішніх бірж цифрових валют, що працюють в Японії. Весь необхідний капітал повинен зберігатися в Японії.

В Японії державний міністр для фінансових послуг регулює основний фінансовий i інвестиційний орган держави Агентство фінансових послуг (Financial Services Agency, FSA)

FSA складається із таких підрозділів ${ }^{3}$ :

- Розробка стратегії та Бюро управління;

- Бюро з питань політики та ринків;

- Виконавче бюро дипломованих бухгалтерів та наглядової ради;

- Виконавче бюро Комісії з нагляду за цінними паперами та біржами тощо.

Важливим підрозділами FSA у галузі інвестування є:

1. Офіс освіти інвесторів, що здійснює планування та вироблення політики основних заходів політики для сприяння стабільному нарощуванню активів громадян;

2. Офіс з досвідченого управління активами, що забезпечує планування, формування політики та координація щодо розвитку управління активами;

3. Офіс користувачів фінансових послуг, що обробляє скарги чи надає інформацію стосовно запитів інвесторів;

На разі Уряд Японії створює офіси INVEST JAPAN у відповідних міністерствах та відомствах, щоб служити єдиними контактними точками для іноземних інвесторів, які шукають інформацію або допомогу в організації бізнесу в Японії. Офіси також розташовані в Міністерстві економіки, торгівлі та промисловості, його регіональних бюро та в Департаменті економіки, торгівлі та промисловості Генерального бюро Окінави.

Для сприяння інвестицій в Японії уряд Японії створив "Інвестиційні японські центри підтримки бізнесу (IBSC)", які будуть єдиними центрами підтримки та інформації про інвестиції. IBSC надають різну інформацію щодо інвестиційних процедур іноземним компаніям, що створюють свою діяльність в Японії.

Крім того, відповідні міністерства та відомства працюють з єдиними контактними пунктами, які називаються "Invest Japan Offices", який може направити інвесторів до підрозділу (у межах певного міністерства / відомства), відповідального за певну процедуру.

Для розвитку міжнародного інвестування Японія здійснила ряд незвичних дій в нефінансовій сфері, до прикладу:

- Здійснює роботу з усунення мовних бар'єрів у магазинах та ресторанах;

\footnotetext{
${ }^{1}$ Bank of Japan (2020). Monetary Policy <www.boj.or.jp/en/mopo/measures/term_cond/index.htm/> (2020, листопад, 03).

2 Toyama, H. (2020) The monetary, regulatory and competitive implications of the restructuring of the Japanese banking industry. BIS <https://www.bis.org/publ/confp07m.pdf/> (2020, листопад, 23).

${ }^{3}$ Bank of Japan (2020). Monetary Policy <www.boj.or.jp/en/mopo/measures/term_cond/index.htm/> (2020, листопад, 03).
} 
- Постійно покращує підключення до Інтернету (безкоштовний Wi-Fi);

- Збільшує кількість ділових літаків в регіональних аеропортах;

- Посилює консультаційні служби для іноземного бізнесу державними міністрами.

В Японії є значна кількість інвестиційних фондів. Історично Японія зарекомендувала себе багатим угіддям для фондів, здатних шукати та інвестувати в компанії, що максимально використовують переважні можливості. Японські фонди, включені до списку Fidelity Select 50, є "біржовиками", але з різними стилями інвестування.

Японський фонд Бейлі Гіффорда займає давню позицію в списку Select 50 і отримує вигоди від найбільшої команди інвестиційних фахівців за межами Японії. Фонд фокусується на провідних японських компаніях, що пропонують привабливе та стійке зростання доходів. В даний час він має великі пакети акцій технологічного конгломерату SoftBank, менеджера активів Sumitomo Mitsui Trust та нафтової компанії INPEX. Sony також потрапляє до поточних 10 фондів Фонду.

Японський фонд акціонерного капіталу "Ліндселл Поїзд" - відносно новачок у списку "Вибрати 50". Вона орієнтована на компанії з високою та стабільною віддачею капіталу та низькою капіталомісткістю. Він набагато менш схильний до бізнесу, який залежить від поліпшення економіки Японії, ніж деякі інші.

Нещодавнє доповнення до Select 50- це фонд Man GLG CoreAlpha. Він є найбільш орієнтованим на вартість 3 усіх трьох фондів, що починається, зосереджуючись на 300 найбільших японських компаніях, що торгують за низькими оцінками. Нині великі холдинги включають деякі відомі в усьому світі імена, включаючи Honda, Toyota та Canon.

Зараз Японії потрібні каталізатори для підвищення довіри інвесторів, бізнесу та споживачів. Олімпійські ігри в Токіо в 2021 р. та поштовх до туризму, які вони спричинять, має позитивно відобразитися на секторі інвестицій.

Висновки $з$ дослідження. Усі країни характеризуються певними особливостями, різноманітними суб'єктами регулювання та власними законами. Проте існують певні спільні тенденції, які варто враховувати при розробленні кредитно-інвестиційної політики для України. У усіх аналізованих державах є державний орган, що забезпечує захист споживачів шляхом нагляду та експертизи, досліджень та аналізу виникаючих проблем та тенденцій у фінансово-кредитній та інвестиційних сферах. Такі органи активно боряться за права інвесторів, а також значно впливають на усі фінансові та інвестиційні інституції. В Україні існує Фонд гарантування вкладів фізичних осіб, що Україні, здійснює спеціальні функції у сфері гарантування вкладів фізичних осіб та виведення неплатоспроможних банків з ринку. Проте цей орган не має таких повноважень, якими наділені суб'єкти в розвинених державах. До прикладу, лише Комісія з цінних паперів і бірж США з метою переслідування фінансових установ, що спричинили кризу, загалом стягнула 3204 юридичних чи фізичних осіб та зібрала близько 4 мільярдів доларів штрафу, зневаги та інших грошових пільг.

Варто зазначити, що потребують подальшого дослідження інші існуючі моделі кредитноінвестиційної політики (країн СС, Канади, Австралії тощо), а також важливим є розроблення вітчизняної консолідованої моделі кредитно-інвестиційної політики з метою ï̈ впровадження для покращення інвестиційного клімату в нашій державі, динаміки кредитно-інвестиційної діяльності та, як наслідок, покращення усіх макропоказників держави.

\section{Referenses:}

1. Karbivnychyy, I. V. (2011). Mekhanizm formuvannya ta realizatsiyi kredytnoyi polityky banku [The mechanism of formation and realization of credit policy of bank]: avtoreferat dysertatsiyi na zdobuttya naukovoho stupenya kandydata ekonomichnykh nauk [the dissertation author's abstract on competition of a scientific degree of the candidate of economic sciences]. Sumy: Ukrainian Academy of Banking of the National Bank of Ukraine. Electronic Sumy State University Institutional Repository <https://essuir.sumdu.edu.ua/bitstream-download/123456789/ 51574/1/Karbivnychuj_credit_policy_in_banks.pdf;jsessionid=1D23801CD55539E8B732560AC0F960B7> (2020, october, 15) [in Ukrainian].

2. Rusina, Yu. O., Kovtun, M. V. (2014). Mekhanizm formuvannia ta realizatsii kredytnoi polityky banku [The mechanism of formation and realization of the credit policy of bank]. Ekonomika. Upravlinnia. Innovatsii [Economy. Management. Innovation], 1(11) <http://nbuv.gov.ua/UJRN/eui_2014_1_52 >(2020, october, 15) [in Ukrainian].

3. Tsanko, O. (2016). Teoretychni osnovy formuvannia investytsinoi polityky: rehionalnyi aspekt [Theoretical bases of investment policy formation: regional aspect]. Efektyvnist derzhavnoho upravlinnia [Efficiency of public administration], 1/2 (46/47), 2, 92-99. [in Ukrainian]. 
4. Sheverdina, O. (2012). Investytsiina polityka Ukrainy yak obiekt derzhavnoi ekonomichnoi polityky [Ukraine's investment policy as an object of state economic policy]. Derzhavna polityka [State policy], 4, 111-117. [in Ukrainian]

5. Turkeshi, N. (2016). The impact of monetary instruments in the development of monetary policy in the republic of Macedonia. Academic Journal of Interdisciplinary Studies, 5 (3 S1). DOI: 10.5901/ajis.2016.v5n3s1p539. [in English].

6. Liuzniak, M. E., Bartosh, O. M. (2011). Instrumenty hroshovo-kredytnoi polityky NBU ta yikh vplyv na depozytnyi i kredytnyi rynky [Monetary policy instruments of the NBU and their impact on deposit and credit markets]. Efektyvna ekonomika [Efficient economy], 12 <http://nbuv.gov.ua/UJRN/efek_2011_12_21> (2020, November, 25). [in Ukrainian].

7. Bank of England (2020). Prudential regulation <https://www.bankofengland.co.uk/prudential-regulation> (2020, November, 05). [in English].

8. Bank of Japan (2020). Monetary Policy <www.boj.or.jp/en/mopo/measures/term_cond/index.htm/> (2020, November, 05). [in English].

9. Board of Governors of the Federal Reserve System (2020). Recent Developments $<$ https://www.federalreserve.gov/aboutthefed/structure-federal-reserve-system.htm> (2020, November, 05). [in English].

10. Farrell, J., Hedges, K. (2012). The JOBS Act: What Startups and Small Businesses Need to Know [Infographic]. Forbes <https://www.forbes.com/sites/work-in-progress/2012/09/21/the-jobs-act-what-startups-and-smallbusinesses-need-to-know-infographic/?sh=73f4baf11067> (2020, November, 05). [in English].

11. FCA (2020). Homepage <https://www.fca.org.uk/> (2020, November, 05). [in English].

12. Federal Open Market Committee (2020). Federal Open Market Committee <https://www.newyorkfed.org/aboutthefed/fedpoint/fed48.html> (2020, November, 05). [in English].

13. Global Legal Insights (2020). Regulatory architecture: overview of banking regulators and key regulations $<$ www.globallegalinsights.com/practice-areas/banking-and-finance-laws-and-regulations/unitedkingdom\#chaptercontent2> (2020, November, 05). [in English].

14. SEC (2020). Homepage <https://www.sec.gov/> (2020, November, 05). [in English].

15. The White House (2012). President Obama To Sign Jumpstart Our Business Startups (JOBS) Act $<$ https://obamawhitehouse.archives.gov/the-press-office/2012/04/05/president-obama-sign-jumpstart-ourbusiness-startups-jobs-act> (2020, November, 05). [in English].

16. Toyama, H. (2020) The monetary, regulatory and competitive implications of the restructuring of the Japanese banking industry. BIS <https://www.bis.org/publ/confp07m.pdf/> (2020, November, 05). [in English]. 